\title{
SELECTING FOR FOOD-FEED TRAITS IN desi AND kabuli GENOTYPES OF CHICKPEA (Cicer arietinum)
}

\author{
Jane Wamatu ${ }^{1, *}$, Tena Alemu ${ }^{2}$, AdugnaTolera ${ }^{2}$, Mohammed Beyan ${ }^{2}$, Ashraf Alkhtib ${ }^{1}$, Million \\ Eshete $^{3}$, Seid Ahmed ${ }^{1}$, Barbara Rischkowsky ${ }^{1}$
}

${ }^{1}$ International Center for Agricultural Research in Dry Areas (ICARDA), P.O Box 5689, Addis Ababa, Ethiopia

${ }^{2}$ Hawassa University, P.O Box 5, Hawassa, Ethiopia

${ }^{3}$ Ethiopian Institute of Agricultural Research, DebreZeit Agricultural Research Center, P. O. Box 32, DebreZeit, Ethiopia

Received - September 26, 2017; Revision - October 05, 2017; Accepted - December 18, 2017

Available Online - December 27, 2017

DOI: http://dx.doi.org/10.18006/2017.5(6).852.860

\section{KEYWORDS}

Chickpea

Food-feed

Straw

Nutritive value

Genotypic variation

\section{ABSTRACT}

The study explored the genetic and environmental variability in chickpea for food-feed traits. Seventy nine genotypes of 17 early-maturing desi genotypes, 19 early-maturing kabuli genotypes and 43 latematuring kabuli genotypes were evaluated for food-feed traits in 7 trials laid out in a randomized complete block design in 3 locations in Ethiopia. All trials showed wide genotypic ranges in various traits related to grain yield, straw yield and straw quality. Analysis of variance for individual trials showed significant $(\mathrm{P}<0.05)$ effects of genotype, location and their interaction on grain and straw yields, $\mathrm{CP}, \mathrm{IVOMD}$ and NDF in all populations. Correlation analysis exhibited either positive or insignificant correlations with straw yield in all trials. The correlation between IVOMD and grain yield was insignificant in all trials. Grain yield correlated significantly $(\mathrm{P}<0.001)$ and positively to NDF in early maturing kabuli, however, the correlation was moderate $(\mathrm{r}=0.396)$. Grain yield correlated either weakly or insignificantly to $\mathrm{CP}$ and $\mathrm{Ca}$ in the trials. The correlation between $\mathrm{P}$ and grain yield was ignored as the straw content of $\mathrm{P}$ was very small in all genotypes $(<1.78 \mathrm{~g} / \mathrm{kg})$. Weak or absence of correlations between grain yields with straw traits would enable chickpea breeders to manipulate grain yield and straw traits independently. This presents an opportunity to identify parental genotypes for improving grain yield and straw traits for individual locations.
* Corresponding author

E-mail: j.wamatu@cgiar.org (Jane Wamatu)

Peer review under responsibility of Journal of Experimental Biology and Agricultural Sciences.

Production and Hosting by Horizon Publisher India [HPI] (http://www.horizonpublisherindia.in/).

All rights reserved.
All the article published by Journal of Experimental Biology and Agricultural Sciences is licensed under a Creative Commons Attribution-NonCommercial 4.0 International License Based on a work at www.jebas.org.

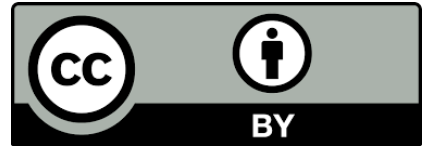




\section{Introduction}

Chickpea is one of the important pulse crops in the world. It ranks second in area and third in production among the pulses worldwide (Bampidisa \& Christodoulou, 2011). It is mainly grown in South Asia, which accounts for more than $75 \%$ of the world chickpea area. India is by far the largest chickpea producing country. Other important chickpea producing countries are Pakistan, Turkey, Mexico, Canada, Australia and Ethiopia. Chickpea is classified into desi chickpea and kabuli chickpea (Bampidisa \& Christodoulou, 2011). Grains of desi chickpea are small in size, light to dark brown in color, smooth or wrinkled and have a thick seed coat. Grains of kabuli chickpea are larger, whitish-cream colored and have a thin seed coat. The desi type is more prominent and accounts for close to $80 \%$ of global chickpea production. The grains are an important source of protein, minerals and vitamins for humans (Bampidisa \& Christodoulou, 2011).Chickpea cultivation produces straw that is used as livestock feed. Generally, residues of pulses and cereals are important sources of feed for livestock raised by resource-poor smallholders in Southern Asia and sub-Saharan Africa. Chickpea straw contains an average of $65 \mathrm{~g} / \mathrm{kg}$ of crude protein (CP), 694 $\mathrm{g} / \mathrm{kg}$ of neutral detergent fiber (NDF), $516 \mathrm{~g} / \mathrm{kg}$ of acid detergent fiber, $111 \mathrm{~g} / \mathrm{kg}$ of acid detergent lignin and $7.7 \mathrm{MJ} / \mathrm{kg}$ of metabolizable energy (Bampidisa \& Christodoulou, 2011). Moreover, growing chickpea improves soil fertility, increases intensity of land use and provides households with cash (Kassie et al., 2009). Despite being a crop of temperate regions, advances in plant breeding from CGIAR (Consultative Group on International Agricultural Research) centers namely ICARDA (International Center for Agricultural Research in the Dry Areas), which holds the world mandate for kabuli chickpea, and ICRISAT (International Crops Research Institute for the Semi-Arid Tropics), has enabled chickpea cultivation to gradually spread to the sub-tropical and tropical regions of Africa, North America and Oceania. Chickpea germplasm developed by ICARDA is distributed and utilized in all these regions. Studies to simultaneously boost grain yield and nutritive traits of grain legume crop residueshave been reported in lentil (Wamatu et al. 2017; Alkhtib et al. 2017), faba bean (Alkhtib et al, 2016b) cowpea (Samireddypalle et al. 2017; Adeyanju et al. 2012). Previous studies on chickpea have reported wide genetic variation in grain yield, the number of secondary branches per plant, the number of pods per plant, biomass yield (Malik et al., 2009) and plant height (Aslamshad et al., 2009) which lead to an exploitable genetic variation in straw quality and yield. Furthermore, studies have reported an existence of positive and significant correlation between grain yield and the number of secondary branches per plant, plant height, number of pods per plant and biomass yield (Malik et al., 2009; Ali \& Ahsan, 2012) which points to a possible positive correlation between grain yield with straw yield and nutritive quality. Therefore, the aim of this study was to determine varietal and environmental variations in straw traits in 79 genotypes across desi and kabuli types of chickpea and to evaluate their food-feed relationships. This is the preliminary stage in a series of steps to identify genotypes with food-feed traits. Evaluation of genotypic variation in yield and quality parameters of straw and food-feed relations would help chickpea breeders design appropriate approaches towards dual purpose food-feed (dual purpose) genotypes of chickpea to address needs for human food and livestock feed in mixed crop-livestock farming systems in developing countries.

\section{Materials and Methods}

\subsection{Experimental layout and the chickpea cultivars}

Seventy-nine (79) genotypes of chickpea were tested in 7 trials in 3 Ethiopian sites; Akaki $\left(08^{\circ} 53^{\prime} \mathrm{N} 38^{\circ} 49^{\prime} \mathrm{E}\right)$, Minjar (08 $44^{\circ} \mathrm{N}$ $\left.38^{\circ} 58^{\prime} \mathrm{E}\right)$, and Chefe Donsa $\left(08^{\circ} 57^{\prime} \mathrm{N} 39^{\circ} 06^{\prime} \mathrm{E}\right)$ located in the Central Highlands at altitudes of 2200, 1810 and 2450 m.a.s.1 respectively and annual rainfall of $1025 \mathrm{~mm}, 867 \mathrm{~mm}$ and 843 $\mathrm{mm}$ respectively (Table 1 ). The Ethiopian Institute of Agricultural

Table 1 Experimental layout of the trails

\begin{tabular}{|c|c|c|c|c|c|c|}
\hline Trail code & Type & Location & Maturity type & Genotypes & $\begin{array}{c}N \\
\text { Blocks }\end{array}$ & Observations \\
\hline$N V T-D-A K$ & desi & Akaki & Early & $17 *$ & 4 & 68 \\
\hline$N V T-D-C D$ & desi & ChefeDonsa & Early & $17 *$ & 4 & 68 \\
\hline$N V T-K-P E-A K$ & kabuli & Akaki & Late & $18 \dagger$ & 4 & 72 \\
\hline$N V T-K-P E-C D$ & kabuli & ChefeDonsa & Late & $18 \dagger$ & 4 & 72 \\
\hline$P V T-K-P E-A K$ & kabuli & Akaki & Late & $25 \neq$ & 3 & 75 \\
\hline$P V T-K-P E-C D$ & kabuli & ChefeDonsa & Late & $25 \neq$ & 3 & 75 \\
\hline$P V T-K-L M S-M N$ & kabuli & Minjar & Early & 19 & 3 & 57 \\
\hline
\end{tabular}

$*, \dagger$ and $\$$ indicate to similar group of genotypes.

Journal of Experimental Biology and Agriculture Science http://www.jebas.org 
Research (EIAR) developed the genotypes, bred for high grain yield, using germplasm selected from ICARDA breeding lines. Elite genotypes were drawn from 2014 preliminary variety trials (PVT) and national variety trials (NVT) of the Ethiopian Chickpea Improvement Program selected based on their high grain yield and other agronomic traits in potential environments (PE) and low moisture stress environments (LMS). Seventeen genotypes of early-maturing desi (D) were grown in 2 locations viz. Akaki and ChefeDonsa. Nineteen early-maturing kabuli(K) genotypes were evaluated at one location (Minjar). Twenty-five late-maturing kabuli genotypes were evaluated in Akaki and ChefeDonsa. The 7 trials are identified by their codes (Table 1) which indicate which varietal trials the genotypes were drawn from (PVT, NVT), the chickpea type (D, K), the type based on physiological maturity (PE: late maturing, LMS: early maturing) and the locations they were planted ( $\mathrm{AK}, \mathrm{CD}, \mathrm{MN})$. In all trials, randomized complete block design (RCBD) was used with three or four replications (Table 1). Fields were blocked based on slope. A unit plot measured $4 \mathrm{~m} \times 0.8 \mathrm{~m}$. Spaces between rows were 20 $\mathrm{cm}$ while spaces between plants were $2 \mathrm{~cm}$. Trials were hand planted in July 2015using recommended agronomic packages as optimized by EIAR for each site. At physiological maturity, plots were manually harvested from two $1.6 \mathrm{~m}^{2}$ areas laid over two middle rows of each plot. The biomass was air-dried in the field, after which grain was removed and weighed. Straw yield was calculated by subtracting grain yield from total biomass yield. Sub-samples of $500 \mathrm{~g}$ of representative straw were taken from each plot for chemical composition and digestibility analysis

\subsection{Straw quality analysis}

After oven-drying at $100^{\circ} \mathrm{C}$ for $24 \mathrm{~h}$, straw samples were ground to pass through a $1 \mathrm{~mm}$ sieve mesh. The samples were analyzed using Near Infrared Reflectance Spectroscopy (NIRS) and conventional wet chemistry. The NIRS instrument, Foss Forage Analyzer 5000 with the software package Win ISI II in the 1108 $2492 \mathrm{~nm}$ spectra range was used to scan lentil straw samples and a good-of-fitness lentil NIRS equation was used for the prediction of dry matter (DM), nitrogen, neutral detergent fiber (NDF) and in vitro digestibility (IVOMD). Validation of the NIRS equation was undertaken using conventional wet chemistry, whereby $20 \%$ representative samples were analyzed for $\mathrm{DM}$ and crude protein (CP) according to the methodology of AOAC (2000). Dry matter was determined by oven drying at $105{ }^{\circ} \mathrm{C}$ overnight (method 934.01). Ash was determined by burning in a muffle furnace at $500{ }^{\circ} \mathrm{C}$ overnight (method 942.05). Nitrogen content was determined by Kjeldahl method using Kjeldahl (protein/nitrogen) Model 1026 (Foss Technology Corp.), (method 954.01). A conversion factor of 6.25 was used to convert nitrogen to crude protein. Neutral detergent fiber, acid detergent fiber (ADF) and lignin were determined as described by Van Soest \& Robertson
(1985). Neutral detergent fiber was did not involve use of heat stable amylase and the result was expressed exclusive of residual ash. Acid detergent fiber was expressed without residual ash. Lignin was determined by solubilisation of cellulose with sulphuric acid. In vitro organic matter digestibility was measured in rumen microbial inoculum using in vitro gas production technique. The buffer solution was prepared according to the method described by Menke \& Steingass (1988). Rumen fluid was collected prior to morning feeding using a vacuum pump from three ruminally cannulated cows fed a total mixed ration of grass hay $(790 \mathrm{~g} / \mathrm{kg})$, wheat bran $(203 \mathrm{~g} / \mathrm{kg})$, salt $(3.2 \mathrm{~g} / \mathrm{kg})$ and a mineral and vitamin mixture $(4.6 \mathrm{~g} / \mathrm{kg})$ on a DM basis. Use of cows was assessed and approved by the Environmental and Occupational Health and Safety Unit of ILRI. The rumen fluid from the cows was composited $(1: 1, \mathrm{v} / \mathrm{v})$, filtered through four layers of cheese cloth, and added to the buffer solution $(1: 2, \mathrm{v} / \mathrm{v})$, which was maintained in a water bath at $39^{\circ} \mathrm{C}$ under continuous flushing with $\mathrm{CO}_{2}$. The buffered rumen fluid $(30 \mathrm{ml})$ was pipetted into $100 \mathrm{ml}$ syringes containing $0.2 \mathrm{~g}$ of sample and immediately placed into a water bath at $39{ }^{\circ} \mathrm{C}$. Gas production was recorded after 24 hours of incubation and used to calculate IVOMD according to Menke et al. (1979) equations suitable for legume hays as follows:

$\operatorname{IVOMD}(\mathrm{g} / \mathrm{kg})=14.88+0.889 G P+0.45 C P+0.0651 X A$

Where GP: $24 \mathrm{~h}$ net gas production $(\mathrm{ml} / 200 \mathrm{mg})$; CP: Crude protein (g/kg DM); XA: Ash content (g/kg DM).

$\mathrm{Ca}$ and $\mathrm{P}$ were analyzed usingAtomic absorption spectroscopy (The Perkin-Elmer Corporation, 1996)

Laboratory analyses were undertaken at the Animal Nutrition Laboratories of the International Livestock Research Institute (ILRI) in Addis Ababa, Ethiopia and Patencheru, India.

\subsection{Calculations and statistical analysis}

A general linear model was used to test the effect of variety on grain yield, straw yield and nutritive value parameters of straw. Each trial was analyzed separately according to the following model:

$Y_{i j}=\mu+B_{i}+G_{j}+E_{i j}$

Where: $Y_{\mathrm{ij}}$ : grain/straw traits, $\mu$ : overall mean, $\mathrm{B}_{\mathrm{i}}$ : effect of the block $\mathrm{i}, \mathrm{G}_{\mathrm{j} \text { : }}$ effect of the genotype $\mathrm{j}, \mathrm{E}_{\mathrm{ij}}$ : random error. To evaluate the effect of location and genotype-location interaction $(\mathrm{GxL})$, data from all trials combined and analyzed according to the following model:

$Y_{i j k}=\mu+G_{i}+L_{j}+G L_{i j}+B(L)_{i j}+E_{i j k}$ 
Where: $Y_{i j:}$ grain/straw traits, $\mu$ : overall mean, $G_{i}$ : effect of the genotype $\mathrm{i}, \mathrm{L}_{\mathrm{j}}$ : effect of location $\mathrm{j}, \mathrm{GL}_{\mathrm{ij}}$ : effect of interaction between the genotype and location, $\mathrm{B}(\mathrm{L}) \mathrm{ij}$ : effect of block i within location $\mathrm{j}, \mathrm{E}_{\mathrm{ijk}}$ : random error.

Relationships between grain and straw traits were calculated separately for each trial using Pearson's correlation. Correlations among the nutritive value parameters of straw in each trial were identified using Pearson's correlation. All statistical procedures were carried out using Statistical Analysis System software (SAS, 2012).

\section{Results}

\subsection{Grain and straw yields}

The effect of genotype on grain yield and straw yield was significant $(\mathrm{P}<0.001)$ in all trials (Table 2). The genotypic range of grain yield and straw yield for desi across locations was 2.34 4.7t/ha and $2.1-5.66 \mathrm{t} / \mathrm{ha}$ respectively. The genotypic range of grain yield and straw yield in late maturing kabuli across locations was $1.04-4.0 \mathrm{t} / \mathrm{ha}$ and $1.49-8.74 \mathrm{t} / \mathrm{ha}$ respectively and a range of
$1.08-3.05 \mathrm{t} / \mathrm{ha}$ and $1.43-5.53 \mathrm{t} / \mathrm{ha}$ respectively for early maturing kabuli. The effect of location and $\mathrm{G} \times \mathrm{L}$ for grain yields and straw yields was significant $(\mathrm{P}<0.05)$ in all trials (Table 4$)$.

\subsection{Straw quality traits}

Table 3 shows a highly significant $(\mathrm{P}<0.001)$ effect of genotype on straw nutritive traits. Considering the means of desi trials, the magnitude of range $(\mathrm{g} / \mathrm{kg})$ was 3.1 in $\mathrm{CP}, 12$ in IVOMD, 3 in $\mathrm{NDF}, 0.9$ in $\mathrm{Ca}$ and 0.047 in $\mathrm{P}$. The magnitude of genotypic range $(\mathrm{g} / \mathrm{kg})$ considering all locations of desi population was 32 in $\mathrm{CP}$, 52 in IVOMD, 65 in NDF. 6.2, in $\mathrm{Ca}$ and 0.48 in P. In late maturing kabuli trials, the magnitude of range among the trial means $(\mathrm{g} / \mathrm{kg}$ ) was 2.2 for CP, 16 for IVOMD, 24 for NDF, 0.6 for $\mathrm{Ca}$ and 0.231 for P. Considering all locations, the magnitude of genotypic range in late maturing kabuli genotypes $(\mathrm{g} / \mathrm{kg})$ in case of CP, IVOMD, NDF, Ca and P was 31.6, 122, 81, 8.9 and 0.945 respectively. In early maturing kabuli, the magnitude of genotypic range $(\mathrm{g} / \mathrm{kg})$ in $\mathrm{CP}$, IVOMD, NDF, Ca and $\mathrm{P}$ was $16.4,58,119$, 4.3 and 1.08 respectively. The effect of location and GxL was significant $(\mathrm{P}<0.05)$ in all trials for $\mathrm{CP}$, IVOMD and NDF (Table 4). Genetic-location interaction was not significant for $\mathrm{Ca}$ in all trials. GxL interaction was not significant for $\mathrm{P}$ in desi.

Table 2 Genotypic variation ingrain yields and straw yields in desi and kabuli chickpea genotypes

\begin{tabular}{|c|c|c|c|c|c|}
\hline $\begin{array}{l}\text { Trial code } \\
\text { Grain yield (t/ha) }\end{array}$ & Mean & Min & $\operatorname{Max}$ & Range & SEM \\
\hline NVT-D-AK & 3.11 & 2.34 & 3.88 & 1.54 & 0.321 \\
\hline NVT-D-CD & 3.68 & 2.5 & 4.7 & 2.2 & 0.552 \\
\hline PVT-K-LMS-MN & 2.12 & 1.08 & 3.05 & 1.97 & 0.353 \\
\hline NVT-K-PE-AK & 2.87 & 1.63 & 3.88 & 2.22 & 0.281 \\
\hline NVT-K-PE-CD & 2.06 & 1.15 & 3.52 & 2.37 & 0.332 \\
\hline PVT-K-PE-AK & 2.63 & 1.46 & 4 & 2.54 & 0.264 \\
\hline PVT-K-PE-CD & 1.7 & 1.04 & 3.39 & 2.35 & 0.433 \\
\hline \multicolumn{6}{|l|}{ Straw yield (t/ha) } \\
\hline NVT-D-AK & 2.69 & 2.1 & 3.41 & 1.31 & 0.4 \\
\hline NVT-D-CD & 4.88 & 3.39 & 5.66 & 2.27 & 0.632 \\
\hline PVT-K-LMS-MN & 2.79 & 1.43 & 5.53 & 4.1 & 0.493 \\
\hline NVT-K-PE-AK & 3.95 & 1.6 & 5.2 & 3.6 & 0.521 \\
\hline NVT-K-PE-CD & 4.17 & 2.19 & 6.87 & 4.68 & 0.752 \\
\hline PVT-K-PE-AK & 4.28 & 1.49 & 7.1 & 5.61 & 0.752 \\
\hline PVT-K-PE-CD & 5.30 & 3.7 & 8.74 & 5.04 & 0.24 \\
\hline
\end{tabular}

The effect of genotype on grain and straw yields is significant $(\mathrm{P}<0001)$ in all trials 
Table 3 Genotypic variation in straw nutritive parameters in desi and kabuli chickpea genotypes

\begin{tabular}{|c|c|c|c|c|c|}
\hline $\begin{array}{l}\text { Trial code } \\
\mathrm{CP}(\mathrm{g} / \mathrm{kg} \mathrm{DM})\end{array}$ & Mean & Min & Max & Range & SEM \\
\hline NVT-D-AK & 51.5 & 39 & 59.8 & 20.8 & 2 \\
\hline NVT-D-CD & 48.4 & 34 & 64 & 30 & 2.21 \\
\hline PVT-K-LMS-MN & 59.9 & 51.1 & 67.5 & 16.4 & 3.72 \\
\hline NVT-K-PE-AK & 49.5 & 37.1 & 56.9 & 19.8 & 2.82 \\
\hline NVT-K-PE-CD & 49.9 & 39.1 & 56.4 & 17.3 & 3.11 \\
\hline PVT-K-PE-AK & 48.2 & 33.2 & 60.9 & 27.7 & 2.92 \\
\hline PVT-K-PE-CD & 50.4 & 36.9 & 64.8 & 27.9 & 4.43 \\
\hline \multicolumn{6}{|l|}{ IVOMD (g/kg DM) } \\
\hline NVT-D-AK & 496 & 487 & 516 & 29 & 4.32 \\
\hline NVT-D-CD & 484 & 464 & 512 & 48 & 4.61 \\
\hline PVT-K-LMS-MN & 477 & 448 & 506 & 58 & 8.22 \\
\hline NVT-K-PE-AK & 494 & 479 & 507 & 28 & 4.34 \\
\hline NVT-K-PE-CD & 483 & 477 & 492 & 15 & 4.13 \\
\hline PVT-K-PE-AK & 499 & 482 & 521 & 39 & 5.82 \\
\hline PVT-K-PE-CD & 490 & 470 & 536 & 66 & 6.41 \\
\hline \multicolumn{6}{|l|}{$\mathrm{NDF}(\mathrm{g} / \mathrm{kg} \mathrm{DM})$} \\
\hline NVT-D-AK & 724 & 712 & 743 & 31 & 9.72 \\
\hline NVT-D-CD & 727 & 688 & 753 & 65 & 11.2 \\
\hline PVT-K-LMS-MN & 750 & 679 & 798 & 119 & 13.6 \\
\hline NVT-K-PE-AK & 716 & 701 & 740 & 39 & 9.1 \\
\hline NVT-K-PE-CD & 740 & 720 & 763 & 43 & 9.22 \\
\hline PVT-K-PE-AK & 721 & 682 & 749 & 67 & 16 \\
\hline PVT-K-PE-CD & 730 & 692 & 755 & 63 & 12.7 \\
\hline \multicolumn{6}{|l|}{$\mathrm{Ca}(\mathrm{g} / \mathrm{kg})$} \\
\hline NVT-D-AK & 15.3 & 13.7 & 17.9 & 4.2 & 0.64 \\
\hline NVT-D-CD & 14.4 & 11.7 & 16.9 & 5.2 & 0.454 \\
\hline PVT-K-LMS-MN & 11.5 & 9 & 13.3 & 4.3 & 0.56 \\
\hline NVT-K-PE-AK & 15.2 & 13.4 & 18.4 & 5 & 0.6 \\
\hline NVT-K-PE-CD & 14.1 & 11.8 & 17.7 & 5.9 & 0.48 \\
\hline PVT-K-PE-AK & 15.2 & 12.1 & 20.5 & 8.4 & 0.483 \\
\hline PVT-K-PE-CD & 13.6 & 11.6 & 18.1 & 6.5 & 0.818 \\
\hline \multicolumn{6}{|l|}{$P(g / k g)$} \\
\hline NVT-D-AK & 0.343 & 0.135 & 0.615 & 0.48 & 0.072 \\
\hline NVT-D-CD & 0.39 & 0.289 & 0.615 & 0.326 & 0.043 \\
\hline PVT-K-LMS-MN & 1 & 0.7 & 1.78 & 1.08 & 0.088 \\
\hline NVT-K-PE-AK & 0.135 & 0.06 & 0.266 & 0.206 & 0.032 \\
\hline NVT-K-PE-CD & 0.20 & 0.09 & 0.4 & 0.31 & 0.065 \\
\hline PVT-K-PE-AK & 0.111 & 0.017 & 0.21 & 0.193 & 0.036 \\
\hline PVT-K-PE-CD & 0.342 & 0.03 & 0.962 & 0.932 & 0.08 \\
\hline
\end{tabular}

The effect of genotype on nutritive value parameters is significant $(\mathrm{P}<0001)$ in all trials. $\mathrm{CP}$, crude protein; IVOMD, in vitro organic matter digestibility; NDF, neutral detergent fiber; $\mathrm{Ca}$, calcium; $\mathrm{P}$, Phosphorus. 
Table 4 Mean of squares of the effect oflocation and genotype-location interaction

\begin{tabular}{|c|c|c|c|c|c|c|}
\hline \multicolumn{7}{|c|}{ Source of variance } \\
\hline & Trial type & Chickpea type & Maturity type & Locations & Location & $\mathrm{G} \times \mathrm{L}$ \\
\hline Grain yield & \multirow{7}{*}{ NVT } & \multirow{7}{*}{ desi } & \multirow{7}{*}{ Early maturing } & \multirow{7}{*}{$\begin{array}{l}\text { Akaki, } \\
\text { ChefeDonsa }\end{array}$} & 9.70 & 0.657 \\
\hline Straw yield & & & & & 156 & 149 \\
\hline $\mathrm{CP}$ & & & & & 1017 & 188 \\
\hline NDF & & & & & 1295 & 674 \\
\hline IVOMD & & & & & 6652 & 377 \\
\hline $\mathrm{Ca}$ & & & & & 26 & $1.91 \dagger$ \\
\hline $\mathrm{P}$ & & & & & 0.077 & $0.024 \dagger$ \\
\hline Grain yield & \multirow{7}{*}{ NVT } & \multirow{7}{*}{ kabuli } & \multirow{7}{*}{ Late maturing } & \multirow{7}{*}{$\begin{array}{l}\text { Akaki, } \\
\text { ChefeDonsa }\end{array}$} & 25.1 & 1.15 \\
\hline Straw yield & & & & & 0.26 & 2.96 \\
\hline $\mathrm{CP}$ & & & & & 145 & 85 \\
\hline NDF & & & & & 15674 & 342 \\
\hline IVOMD & & & & & 2984 & 113 \\
\hline $\mathrm{Ca}$ & & & & & 81.2 & $1.59 \dagger$ \\
\hline $\mathrm{P}$ & & & & & 2.15 & 0.11 \\
\hline Grain yield & \multirow{7}{*}{ PVT } & \multirow{7}{*}{ kabuli } & \multirow{7}{*}{ Late maturing } & \multirow{7}{*}{$\begin{array}{l}\text { Akaki, } \\
\text { ChefeDonsa }\end{array}$} & 46 & 1 \\
\hline Straw yield & & & & & 11 & 3.18 \\
\hline $\mathrm{CP}$ & & & & & 5698 & 690 \\
\hline $\mathrm{NDF}$ & & & & & 303 & 825 \\
\hline IVOMD & & & & & 964 & 280 \\
\hline $\mathrm{Ca}$ & & & & & 97.5 & $1.5 \dagger$ \\
\hline $\mathrm{P}$ & & & & & 1.14 & 0.079 \\
\hline
\end{tabular}

$\mathrm{G} \times \mathrm{L}$, genotype-location interaction; $\uparrow \mathrm{P}>0.05$ otherwise $\mathrm{P} \leq 0.05$; CP, crude protein; IVOMD, in vitro organic matter digestibility; NDF, neutral detergent fiber; $\mathrm{Ca}$, calcium; $\mathrm{P}$, Phosphorus; NVT, national varieties trial; PVT, preliminary varieties trial.

\subsection{Correlations between nutritive value parameters}

Table 5 shows the correlations between nutritive value parameters of chickpea straw in each trial. In desi types, early and late maturing kabuli types, NDF correlated strongly and negatively with IVOMD while other correlations were either moderate or weak.

\subsection{The correlation between grain and straw traits}

The correlations between grain yield and straw traits are presented in Table 6. Grain yield either correlated positively $(\mathrm{P}<0.05)$ or did not correlate to straw yield in all trials. The correlations between grain yield and nutritive value traits straw were insignificant in desi trials. In early maturing kabuli genotypes, grain yield correlated moderately and positively with $\mathrm{NDF}(\mathrm{r}=0.396 ; \mathrm{P}<0.05)$ and $\mathrm{Ca}(\mathrm{r}=0.347 ; \mathrm{P}<0.05)$. In late maturing kabuli genotypes, the correlation between grain yield and $\mathrm{CP}$ was weak and positive in NVT-K-PE-AK $(r=0.28 ; \mathrm{P}<0.05)$, moderate and positive in PVT-KPE-AK $(r=0.41 ; \mathrm{P}<0.05)$ and moderate but negative in NVT-K-PE$\mathrm{CD}(\mathrm{r}=-0.37 ; \mathrm{P}<0.05)$. Genotypes in the trial NVT-K-PE-AK showed a weak and negative correlation between grain yield and $\mathrm{Ca}(\mathrm{r}=-0.298 ; \mathrm{P}<0.05)$. The correlation between grain yield and $\mathrm{P}$ was ignored as $\mathrm{P}$ content of straw was very low $(<1.78 \mathrm{~g} / \mathrm{kg})$. 
Table 5 Correlations among nutritive value parameters of chickpea straw

\begin{tabular}{|c|c|c|c|}
\hline $\mathrm{CP}$ & $\mathrm{NDF}$ & IVOMD & $\mathrm{Ca}$ \\
\hline \multicolumn{4}{|l|}{ Desi } \\
\hline $\mathrm{CP}$ & 0.61 & -0.553 & -0.46 \\
\hline $\mathrm{NDF}$ & & -0.796 & Ns \\
\hline IVOMD & & & 0.234 \\
\hline \multicolumn{4}{|l|}{ Early maturing kabuli } \\
\hline $\mathrm{CP}$ & $\mathrm{ns}$ & $\mathrm{ns}$ & -0.508 \\
\hline $\mathrm{NDF}$ & & -0.7 & Ns \\
\hline IVOMD & & & Ns \\
\hline \multicolumn{4}{|l|}{ Late maturing kabuli } \\
\hline $\mathrm{CP}$ & 0.309 & -0.324 & -0.227 \\
\hline $\mathrm{NDF}$ & & -0.702 & ns \\
\hline IVOMD & & & -0.164 \\
\hline
\end{tabular}

$\mathrm{CP}$, crude protein; IVOMD, in vitro organic matter digestibility; $\mathrm{NDF}$, neutral detergent fiber.

Table 6 Correlation coefficients between grain yield and straw traits of chickpea

\begin{tabular}{|c|c|c|c|c|c|}
\hline \multirow{2}{*}{ Trial code } & \multicolumn{5}{|c|}{ Grain yield } \\
\hline & Straw yield & $\mathrm{CP}$ & IVOMD & $\mathrm{NDF}$ & $\mathrm{Ca}$ \\
\hline \multicolumn{6}{|l|}{ Desi } \\
\hline NVT-D-AK & 0.36 & ns & ns & ns & ns \\
\hline NVT-D-CD & 0.62 & ns & ns & ns & ns \\
\hline \multicolumn{6}{|c|}{ Early maturing kabuli } \\
\hline PVT-K-LMS-MN & ns & ns & ns & 0.396 & 0.347 \\
\hline \multicolumn{6}{|l|}{ Late maturing kabuli } \\
\hline NVT-K-PE-AK & 0.64 & 0.28 & ns & ns & -0.298 \\
\hline NVT-K-PE-CD & 0.65 & -0.37 & ns & ns & ns \\
\hline PVT-K-PE-AK & 0.53 & 0.41 & ns & ns & ns \\
\hline PVT-K-PE-CD & 0.78 & ns & ns & ns & $\mathrm{ns}$ \\
\hline
\end{tabular}

ns, $\mathrm{P}>0.05$ otherwise $\mathrm{P} \leq 0.05 ; \mathrm{CP}$, crude protein; IVOMD, in vitro organic matter digestibility;

NDF, neutral detergent fiber

\section{Discussion}

\subsection{Grain and straw yields}

High demand for crop residue biomass for livestock feeding inEthiopia under mixed systems has been reported (Alkhtib et al., 2016a). Although, genotypes in the current study were bred for high grain production, wide genotypic range in straw yield was found in both desi and kabuli trials. In agreement with our results, wide genetic variation in grain and straw yields has been reported in several crops including maize (Ertiro et al., 2013), pearl millet (Blümmel et al., 2010) and durum wheat (Tolera et al., 1999). Wide variability in straw yield can be exploited to improve the straw yield of chickpea. The current results showed that effect of genotype on straw yield depends on the location. Such effects of genetic-environment interaction on crop residue yield was reported by (Ertiro et al., 2013) in maize. This suggests that the effect of location should be considered during efforts targeting enhancement of straw yield of both desi and kabuli chickpea.

\subsection{Straw nutritive traits}

Significant differences were observed among the various genotypes for straw nutritive value which is in agreement with Kafilzadeh \& Maleki (2012). Wide genetic variability in parameters of nutritive value of crop residues has been reported by Ertiro et al. (2013) in maize, Vadiveloo \& Fadel (2009) in rice, Singh \& Shukla (2010) in groundnut. Crude protein content in feeds is very important to achieve optimum rumen activity in addition to ensure adequate dry matter intake. Risco \& Melendez (2011) recommend a minimum of 70-80 g/ $\mathrm{kg}$ and $100-110 \mathrm{~g} / \mathrm{kg}$ of CP in the diet of non-lactating and lactating animals to sustain rumen fermentation. The genotype with the highest content of straw $\mathrm{CP}$ in this study had a value of 67.5 $\mathrm{g} / \mathrm{kg}$, which does not ensure optimum activity of the rumen for non-lactating ruminants. However, crude protein content of crop residue can be improved through agronomic practices, particularly by applying a feasible level of nitrogen fertilization (Blümmel et al., 2007).Rejection of high grain yielding varieties of maize by farmers has been reported because of low dry matter intake of the varieties by livestock (Hellin et al., 2013). Dry matter intake of low-quality roughages is closely and negatively associated with the content of NDF (Horrocks \& Vallentine, 1999). Wide genotypic variation in NDF content of chickpea straw was found in this current study. This suggests that dry matter intake of chickpea straw could be improved by exploiting the natural variability in the straw content of NDF. However, dry matter intake is affected by other factors. Thus, it is imperative to test the palatability of straws of chickpea genotypes developed with desired food-feed 
traits before release. The $\mathrm{Ca}$ of chickpea straw in all genotypes except one in PVT-K-LMS-MN was either equal or higher than $\mathrm{Ca}$ content of green vetch which was reported to be $12 \mathrm{~g} / \mathrm{kg}$ (Heuzé et al., 2015). That implies the possibility of improving Ca of chickpea by selection. However, P content of chickpea straw was considerably lower than vetch straws which have been reported to have $1.3 \mathrm{~g} / \mathrm{kg}$ on average (Heuzé et al., 2015). Thus, no important increase in $\mathrm{P}$ content of chickpea straw is expected to be achieved by selection. It is noteworthy that if chickpea straw constitutes a major portion of diet of lactating cattle, mal absorption of $\mathrm{Ca}$ could be encountered unless the diet is supplemented by an adequate source of P. Results of this study showed that the content of CP, NDF and IVOMD were dependent on location. Therefore, recommendations of chickpea genotypes with desirable food-feed traits should be location-based. The insignificant effect of GxL on Ca content showed that the relative $\mathrm{Ca}$ content of chickpea genotypes is independent of location.

\subsection{Correlations among nutritive value parameters}

The correlations among nutritive value parameters in all trials were generally moderate or weak (except NDF with IVOMD). The results of study revealed that no single parameter consistently showed strong correlations with the other parameters. That means no single parameter can represent the nutritive value of straw, rather data on chemical composition and digestibility has to be collected for all parameters of nutritive value during screenings of genotypes for straw nutritive value. This result is contrary to Alkhtib et al. (2016b) who reported that NDF can represent the nutritive value of faba bean straw.

\subsection{Correlation between the grain yield and straw traits}

Correlations between grain yield and straw yield were inconsistent across genotypes and populations, which is in agreement with Ertiro et al. (2013) in maize. Straw yield correlated either positively with grain yield or insignificantly in some trials. That means improving chickpea for straw yield will not decrease grain yield. The correlation between grain yield and straw yield was inconsistent across trials in all types of chickpea. That means grain yield cannot be used to predict straw yield in chickpea. Whenever straw yield is considered as a selection criteria by chickpea breeders, it has to be measured alongside grain yield. The correlation between grain yield and straw nutritive value parameters were either insignificant or less than $0.41\left(r^{2}<0.16\right)$. That means that no significant change in grain yield of chickpea would be associated with any improvement of straw nutritive value. This is in agreement with Alkhtib et al. (2016b) who reported neutral relationships between grain yield and straw nutritive value in faba bean.

\section{Conclusion}

The existence of wide ranges among genotypes for grain and straw yields and straw nutritive traits is promising for selection of genotypes with superior food-feed traits. The weak relationship between grain and straw traits in most of the trials implies the independent improvement of both food and feed traits. However, currently, breeding programs do not consider straw traits as criteria either for varietal evaluation or for release of new genotypes. Chickpea improvement efforts should give attention to p-investigated. Data on the straw nutritive value in the current study is based on in vitro evaluation, therefore, there is need to confirm these results with animal performance trials before giving final recommendations to farmers. Chickpea straw has high content of $\mathrm{Ca}$, but a very low content of P. When chickpea straw is used as a basal diet for lactating livestock, a feasible supplementation of chickpea straw with a source of $\mathrm{P}$ has to be applied to ensure an optimum utilization of ca. This study shows promise to the possibility for simultaneous improvement of grain yield and straw traits to address the high demand existing for dual-purpose, food-feed type of chickpea genotypes in mixed crop-livestock farming systems using appropriate breeding approaches.

\section{Acknowledgements}

The authors acknowledge the financial support from the CGIAR Collaborative Research Program, Livestock \& Fish and the USAID-funded, Feed the Future initiative, Africa Research in Sustainable Intensification for the Next Generation (Africa RISING). Appreciation to Ethiopian Institute for Agricultural Research, DebreZeit Station for facilitating field activities, Hawassa University, Ethiopia and the Animal Nutrition Laboratory of the International Livestock Research Institute (ILRI) in Addis Ababa, Ethiopia and Patancheru, India for analyses of straw samples.

\section{Conflict of Interest}

Authors would hereby like to declare that there is no conflict of interest that could possibly arise.

\section{References}

Adeyanju A, Ishiyaku M, Echekwu C, Olarewaju J (2012) Generation mean analysis of dual purpose traits in cowpea (Vigna unguiculata). African Journal of Biotechnology 11 : 1047310483.

Alkhtib, A., Wamatu J, Ejeta T, Rischkowsky B (2017) Integrating the straw yield and quality into multi-dimensional improvement of lentil (Lens culinaris). Journal of the Science of Food and Agriculture, 97: 4135-4141. 
Alkhtib A, Wamatu J, Kassie G, Rischkowsky B (2016a) Analysis of crop residue use in small holder mixed farms in Ethiopia. Renewable Agriculture and Food Systems 32:454-462.

Alkhtib A, Wamatu J, Wegi T, Rischkowsky B (2016b) Variation in the straw traits of morphological fractions of faba bean (Vicia faba L.) and implications for selecting for food-feed varieties. Animal Feed Science and Technology 222: 122-131.

Ali Q, Ahsan M (2012) Estimation of genetic variability and correlation analysis for quantitative traits in chickpea (Cicer arietinum L.). International Journal for Agro Veterinary and Medical Sciences 6: 241-249.

AOAC (2000) Official Methods of Analysis. AOAC International, Gaithersburg.

Aslamshad M, Pervez H, Zafar Z, Zia-Ul-Haq M, Nawz H (2009) Evaluation of biochemical composition and physiochemical parameters of from seeds of desichickpea varieties cultivation in arid zones of Pakistan. Pakistan Journal of Botany 41: 655-662.

Bampidisa V, Christodoulou (2011) Chickpeas (Cicer arietinum L.) in animal nutrition: A review. Animal Feed Science and Technology 168: 1-20.

Blümmel M, Bindinger F, Hash C (2007) Management and cultivar effects on ruminant nutritional quality of pearl millet (Pennisetum glaucum (L.) $R, B r$.) Stover. II. Effects of cultivar choice on stover quality and productivity. Field Crops Research 103: $129-138$

Blümmel M, Khan A, Vadez V, Hash C, Rai K(2010) Variability in stover quality traits in commercial hybrids of pearl millet (Pennisetum glaucum (l.) $\quad r . \quad b r$.) and grain-stover trait relationships, hybrids. Animal Nutrition and Feed Technology 10S: 29-38.

Ertiro B, Twumasi-Afriyie S, Blümmel M, Friesen D, Negera D, Worku M, Abakemal D, Kitenge K (2013) Genetic variability of maize stover quality and the potential for genetic improvement of fodder value. Field Crops Research 153: 79-85.

Hellin J, Ernstein O, Beuchelt T, Camacho C, Flores D(2013) Maize stover use and sustainable crop production in mixed croplivestock systems in Mexico. Field Crops Research 153: 12-21.

Heuzé V, Tran G, Baumont R(2015) Common vetch (Vicia sativa). Feedipedia, a programme by INRA, CIRAD, AFZ and FAO. Available on http://feedipedia.org/node/239 access on $25^{\text {th }}$ April, 2016.

Horrocks RD, Vallentine JF (1999) Harvested Forages. Academic Pres, UK.

Kafilzadeh F, Maleki E(2012) Chemical composition, in vitro digestibility and gas production of straws from different varieties and accessions of chickpea. Journal of Animal Physiology and Animal Nutrition 96: 111-118.

Kassie M, Shiferaw B, Asfaw S, Abate T, Muricho G, Ferede S, Eshete M, Assefa K (2009) Current situation and future outlooks of the chickpea sub-sector in Ethiopia.EIAR (Ethiopian Institute of Agricultural Research) and ICRISAT (International Crops Research Institute for the Semi-Arid), India.

Malik S, Bakhsh A, Ahsan M, Iqbal U, Iqbal S (2009) Assessment of genetic variability and interrelationship among some agronomic traits in chickpea. International Journal of Agricultural Biology 12: 814-9596.

Menke K, Raab L, Salewski A, Steingass H,Fritz D, Schneider W (1979) The estimation of thedigestibility and metabolisable energy content of ruminant feeding stuffs from the gas production when they are incubated with rumen liquor.Journal of Agricultural Science 93:217-222.

MenkeK, Steingass H (1988) Estimation of the energetic feed value from chemical composition and in vitro gas production using rumen fluid. Animal Research and Development 28:7-55.

Risco C, Melendez P (2011) Dairy cattle diseases. WileyBlackwell, Iowa.

Samireddypalle A, Boukar O, Grings E, Fatokun CA, Kodukula P, Devulapalli R, Okike I, Blümmel M (2017) Cowpea and groundnut haulms fodder trading and its lessons for multidimensional cowpea improvement for mixed crop livestock systems in West Africa. Frontiers in Plant Science 8:1-9.

SAS (2012)SAS/STAT 12.1 User's GuideSAS Inc., Cary, NC, USA.

Singh S, Shukla G (2010) Genetic diversity in the nutritive value of dual purpose sorghum hybrids. Animal Nutrition and Feed Technology 10S: 93-100.

Perkin-Elmer Corporation (1996) Analytical methods for atomic absorption spectroscopy, USA.

Tolera A, Trygve B, Frik S (1999) The effect of variety on maize grain and crop residue yield and nutritive value of the stover. Animal Feed Science and Technology 79: 165-177.

Vadiveloo J, Fadel J (2009) The response of rice straw varieties to urea treatment. Animal Feed Science and Technology 151: 291298.

Van Soest P, Robertson J (1985) Analysis of forage and fibrous foods, a laboratory manual for Animal Science. Cornell University, New York.

Wamatu J, Mersha A, Tolera A, Beyan M, Alkhtib A, Eshete M, Ahmed S, Rischkowsky B (2017) Selecting for food-feed traits in early and late maturing lentil genotypes (Lens culinaris). Journal of Experimental Biology and Agricultural Sciences 5: 697-705. 